\title{
The Human Resources Revolution: Is it a Productivity Driver?
}

\author{
Kathryn Shaw \\ Carnegie Mellon University
}

Third draft, May 5, 2003

Please Do Not Quote

Prepared for the NBER conference "Innovation Policy and the Economy," April 15, 2003.

I would like to acknowledge the excellent support by the Alfred P. Sloan Foundation, the Russell Sage Foundation, and the Rockefeller Foundation for my ongoing research. Also, my co-authors have contributed very significantly to the research that I refer to herein and to my understanding of these issues, though they are in no way responsible for the views I express below. I thank Brent Boning, Jon Gant, and Casey Ichniowski for their assistance and ongoing collaboration. 


\section{Introduction}

For many years now, business persons have suggested that the primary competitive advantage of firms lies in the quality and optimal use of their workforce (see Business Week, for recent article). On an international basis, the U.S. cannot compete on the basis of low-cost labor, and thus instead must compete by having the highest quality labor, applied to making products more productively and making products that are more quality or R\&D intensive.

There are three possible routes for improving productivity from the optimal use of labor resources - one is to increase the quantity of capital that labor has with which to work, another is to increase the quality of labor, and the third is to improve the management of labor resources to increase their output. There is no doubt that over the long run, rising labor quality and rising amounts of capital in the U.S. has contributed to rising labor productivity (Jorgensen, Ho, Stiroh, 2002). However, the more unknown question is to what degree the improved management of labor resources has contributed to greater productivity or overall performance. That is the primary question addressed in this paper.

I begin by arguing that there has been a major "technology shock" in the form of the use of more innovative human resource management (HRM) practices in the developed countries in the last twenty-five years. Specifically, firms have moved towards the use of practices such as teamwork, problem-solving teams, information sharing, job rotation, and incentive pay-all aimed at eliciting greater effort and effort focused on problem solving on the job. Thus, the key questions are: has there been an evolution towards more innovative HRM practices world-wide; what theoretical impact might these practices have on worker performance levels; have these practices increased productivity or performance and if so how.

I ask, finally, what role might policy play in fostering productivity gains arising from the adoption of innovative HRM practices? Two options are emphasized. First, the government should continue to expand its commitment to elementary education and 
the development of basic skills. Firms in the U.S. today want workers who are capable of solving problems on the job. Thus, even at the fairly low-skilled level of production workers, firms want those who can read, write, do math, and communicate with others. Given these basic skills, firms can build on them with the investment in more firmspecific skills. And these basic skills are best taught in early education, not in later government-sponsored training programs. Second, firms have begun to emphasize their investments in their "knowledge workers" or human capital. While this often refers to the more highly educated worker, it can and should refer as well to the less-educated production worker. However, unlike investments in physical capital or R\&D, the investment in workers is typically not measured or expensed. Many have suggested some government involvement in facilitating better accounting systems that acknowledges, and thus encourages, the investment in "people."

\section{The Macroeconomic Evidence on Productivity Gains}

An important question in recent years is, to what degree did labor resources contribute to the "new economy" of the 1990s? The last half of the 1990s was labeled the "new economy because the trend growth rate of labor productivity rose for an average 1.44 in 1973-1995 to 2.43 percent from 1995-2001, and many believe that higher trend productivity growth continues into the 1990s. Thus, I turn first to the industry growth accounting models to ascertain the sources of that growth.

A consistent picture emerges - the use of information technologies (IT) contributed significantly to the growth of productivity during that period. The IT producing industries experienced very rapid productivity growth, but in addition, the nonIT producing industries also contributed to the growth of productivity (Jorgenson, Ho, and Stiroh, 2002 and Olinor and Sichel, 2002). Of the one percentage point gain in labor productivity (from 1.4 to 2.4 ) in the late 1990 s relative to the previous twenty year period, .56 percentage points was due to capital deepening through the purchase of IT capital (either hardware, software, or communications IT in line 3 of Table 1, Olinor and Sichel, 2002). Thus, the use of IT explains $56 \%$ of the productivity gain. Moreover, looking within the non-IT industries, those industries that were heavy purchasers of IT 
equipment had the highest rates of productivity growth (Bailey, 2002). At the same time, performance gains within the IT-producing sector resulted in a .36 percentage point gain in productivity for the overall economy (lines 10-14 of Table 1). Thus, overall, gains arising from the IT sector account for $92 \%$ of the gains in labor productivity.

Turning to the impact of labor resources, there are two possible roles that human resources might play in the productivity gains. First, increases in labor quality over time could contribute to the gains in productivity-however, the data shows this is not likely to be the case. Using industry-specific national accounts data,. Jorgensen, Ho, and Stiroh (2002) calculate a measure of labor input that incorporates the heterogeneity in labor inputs across industries by using industry specific values for gender, age, job class, and educational attainment, to produce 168 different types of workers for each of their 35 industries. Using these measures, they create a labor quality index for each industry, and then weight it by hours worked in that industry. Given these data, they then show that labor quality did not contribute to the productivity gains over this period. In fact, just as other research has shown (Jorgensen and Stiroh, 2002, Olinor and Sichel, 2002), labor quality fell, and thus it alone would have produced a decline in labor productivity.

The second possible role of human resources arises from the improved use of human capital within firms. Specifically, if firms learned how to better manage their work forces, through the use of innovative human resource practices, then this improved management would result in an increase in total factor productivity. Numerous researchers have speculated that improved HRM practices have contributed to productivity gains (Jorgenson, Ho, and Stiroh, 2002 and Olinor and Sichel, 2002). They have also speculated that a portion of the gain from the investment in information technologies is due to the changes in the use of human resources to complement the investments in information technologies (see also Breshnahan, Brynjolfsson and Hitt, 2002). However, for the purposes of aggregate industry-level growth accounting framework, there is no data on changes in HRM practices by industry over time with which to test that hypothesis. 
Thus, I turn next to an examination of the evidence of the effectiveness of HRM practices, where the evidence comes from firm-level data or production line data. However, before turning to that evidence, I ask the question, why did firms start adopting innovative HRM practices in the 1980s and thus realize the gains from performance during those years?

\section{Technology Shocks}

The evidence below will show that firms began utilizing "innovative" HRM practices in the 1980s and beyond. The question naturally arises, if firms knew of the value of HRM practices, why weren't these practices adopted earlier? I argue that the discovery of the value of these innovative practices was discovered in the U.S in the 1980s, and that this discovery represents a "technology shock," just like the discovery of information technology innovations represent a technology shock.

\section{The Information Technology Shock}

The information technology "shock" is evident in the size of the productivity gains in the IT-producing sector, in the falling prices of their products (per quality unit of computing), and in the higher investments by firms that have resulted from these falling prices. Since 1980, the speed of microprocessers used in pc's has increased more than 100 fold, so that the cost of performing 1 million instructions per second has fallen from $\$ 100$ to less than 20 cents. The cost of a megabyte of hard disk storage has fallen from $\$ 100$ in 1980 to less than 1 cent today. Data transmission also skyrocketed, as fiber optics lowered the costs of sending 1 trillion bits of information from $\$ 120,000$ to 12 cents from 1980 to 1999.

The net effect of these performance gains per dollar of expenditure is that prices of computers and equipment fell 71 percent between 1995 and 2000. Investments by firms followed. Use of the personal computer began in the early 1980s, but its extensive power and very widespread use developed in the 1990s. More recently, in the mid-to-late 1990s, very extensive developments in networking developed-- with within-firm intranets and the Internet for $\mathrm{B} 2 \mathrm{~B}$ and $\mathrm{B} 2 \mathrm{C}$ communications. Thus, as a result of the acceleration 
of technological improvements in computing, investment in computers and software grew at a $19 \%$ annual rate during the 1990s, and accelerated to a $28 \%$ annual rate after 1995. Complementary investment in software also doubled in those years (rising from $\$ 10$ billion in 1980 , to $\$ 50$ billion in 1990 , to $\$ 225$ billion in 1999$)$, though the prices of software only fell by $2 \%$ a year.

\section{The Human Resource Management Technology Shock}

Just as innovations in information technology have produced productivity gains arising from investments in IT, innovations in human resource management (HRM) practices may also have produced productivity gains arising from investments in HRM. These 'innovations' in HRM can also be considered a "technology shock" over the last twenty-five years, though it is more difficult to measure the size of the shock. Robert Cole (2000) describes potential innovations in HRM practices as a shock to managers: twenty-five years ago, the traditional U.S. system of HRM practices gave production workers very little problem-solving involvement when the Japanese demonstrated that participatory practices could raise performance. Cole documents the huge gap in product quality in the U.S. relative to the Japanese in the 1970s and early 1980s, and U.S. managers' eventual discovery that the technology of production had changed. Some innovative firms took up the challenge and adopted innovative HRM, others moved more slowly, and some of the early changers were among Japanese transplants to the U.S. (Cutcher-Gershenfeld, et.al., 1994).

The investment in "innovative HRM" practices varies across firms - both in the extent of use of these practices and in the definition of what constitutes innovative practices. In previous research, we innovative HRM practices are defined as the seven sets of practices that combine to raise employee involvement (Ichniowski, Shaw, and Prennushi, 1997):

- The careful screening and selection of workers is required to obtain those who are more skilled in job-related skills, as well as the "team skills" or "people skills" to work together to solve problems. 
- Formal problem-solving teams, with procedures for their development and use, are introduced to provide production workers with direct input into improving the production process.

- Workers are rotated across jobs to provide training, worker flexibility and to increase teamwork.

- Incentive pay, such as pay-for-performance in piece rates, or in group incentive plans is introduced to offer the incentive for greater employee involvement and to increase production performance.

- Information sharing, in formal meetings or through informal networks, provides the information and motivation for greater involvement and decisionmaking.

- More extensive training increases worker performance, enhances problem solving success and increases skills for day-to-day decisionmaking.

- Job security is used to assure workers that suggestions for improvements in production performance will not result in the direct loss of jobs.

While firms choose different sets of HRM practices in developing, the overall adoption of these individual innovative practices appears to have increased over the last twenty-five years. Lawler, Mohrman, and Ledford (1995) show that Fortune 500 firms substantially increased their use of teams (or work groups) and of self-managed work teams-see Figure 1. In these firms, these practices became more pervasive: the percent of large firms having more than 20 percent of workers participating in work groups rose from $37 \%$ to $65 \%$ from 1987 to 1993 , and the percent of firms having more than 20 percent of workers participating in self-managed teams rose from $20 \%$ to $49 \%$. While the survey does not go back to the early 1980s, earlier questions on total quality management (which is the precursor to teams) suggests that the practices began to be adopted in the 1980s.

Across all types of establishments, including small and non-manufacturing, there has been significant growth in the use of multiple HRM practices in the 1990s. Using survey data of all types of establishments, Osterman finds that from 1992 to 1997, the percent of establishments with two or more practices in use by at least half of the 
workforce rose from $25 \%$ to $38 \%$ when he followed the same establishments over time. Moreover, these practices were sustained within establishments: an "overwhelming majority of establishments in place in 1992 maintained that status in 1997" (2000, page 186). And while team use did not grow in his survey from 1992-1997, the use of other practices did: the percent of establishments that used job rotation rose from $24 \%$ to $47 \%$.

The HRM technology shock is also present in European countries from the 1980s onward. While the levels of HRM in Europe cannot be compared to those in the U.S., because no data sets obtain these cross-continent data, we can compare practices within Europe. Using data from three different sources, Bauer (2002) shows that the adoption of innovative HRM practices that raise teamwork is most prevalent in the Scandinavian countries and the U.K., and the lowest dissemination is in the southern European countries (Greece, Portugal, Spain, and Italy)—see Figure 2 containing EU data. Overall, Germany ranks slightly below average and France slightly above average in the use of teamwork.

The key question is, how has the use of innovative HRM practices changed over time in Europe? Data from Denmark, a country with high current rates of adoption, displays the increases over time (Eriksson, 2002)—see Figure 3. The most remarkable increases have come in the use of teamwork, rising from $27 \%$ of companies prior to 1990 to $42 \%$ in 1996-99, and the levels of use are high as well. As in all studies, in the U.S. and Europe, large firms are most likely to adopt new innovative HRM practices, and firms with a more highly skilled workforce are more likely to adopt innovative practices.

In sum, a conservative assessment suggests that prior to 1980 s, virtually no firms in the U.S. or Europe had HRM practices emphasizing employee involvement, but that their use grow fairly steadily over the 1980s and into the 1990s. The introduction of EI occurred in the early 1980s; by 1990 approximately half of all firms had some innovations; and since 1990 there has been variable, but continued, progress. Thus, to the extent that HRM represents a technology shock, this shock occurred and adjustments 
were made in the 1980s and early 1990s, and perhaps to a lesser extent in the mid-to-later 1990s.

\section{The Effects of HRM Technology Shocks: Building Problem- Solving Capacity}

The Combined Effects of the IT and HRM Technology Shocks: Changes in Decision Rights to Build Problem-Solving Capacity

The advent of innovations in HRM practices and in information technologies is likely to have increased the value of locating decision-making at lower levels in the organization. The typical goal of innovative HRM practices is to move decision rights from managers to workers at lower levels in the organization. For example, Jensen and Mechling (1992) posit that firms should "co-locate" decision-making authority with employees who have the most relevant information. In this section, I describe the investments that firms make to push decision-making down the hierarchy and thus increase performance.

The movement towards greater degrees of worker participation in decisionmaking is likely to have grown over the last twenty-five years as a result of three changes :

1. Firms began to recognize that production workers possess valuable information about the operation of production lines-information that engineers and supervisors often lack. Thus, this discovery of the value of workers' insights is part of the "Japanese technology" shock or HRM shock.

2. The IT revolution resulted in two changes: all individuals now have more information available to them at all levels; and communications are much more rapid and information intensive. These communications links and decentralized information have increased progressively over time, with the latest improvements 
arising from networking and extensive developments in within-firm intranets and the Internet for B2B and B2C communications

3. In today's competitive environment, the competitive advantage of U.S. firms is often in the domain of producing niche products, or products that are $R \& D$ or knowledge intensive. In this environment, employees at all levels are required to undertake problem-solving activities; the days of producing commodities with cheap labor are gone.

Thus, there is a movement towards greater authority for operators to make operating decisions, and firms typically must make other changes in the HRM environment to enhance this change in authority. For example, they must also be given the incentives that motivate good decisions (Jensen and Mechling, 1992; Baker, 1992). ${ }^{1}$ Prior to the Japanese technology revolution, most U.S. firms managed their firms through the use of the "hierarchical control" model of management (Aoki, 1986). Employees are managed through "control"—close supervision rather than involvement and personal incentives or rewards. The use of problem-solving teams, or of greater day-to-day decision-making at lower levels, will tend to be combined with some form of incentive pay that induces workers to want to make more decisions and to be more accountable for those decisions. The complementarity of incentive pay and other HRM practices with problem-solving teams is discussed further below.

As a result of these changes, firms are making new investments in practices to enhance workers' performance - we develop the concept of "problem-solving capacity" to describe the new forms of human capital investment that firms are undertaking to improve problem solving outcomes (Gant, Ichniowski, and Shaw, 2002, Ichniowski, and Shaw, and Gant, 20023). An example helps to clarify the concept of problem-solving capacity. In the traditional steel mill, if a production worker recognizes a quality problem on the line, such as a surface defect in the new steel, he will call the foreman and report the problem (or he will do nothing and let the line continue running). However, if the

\footnotetext{
${ }^{1}$ For more on the assignment of responsibility within firms, see Prendergast (1995), Rosen (1982) and Geanakoplos and Milgrom (1991).
} 
mill introduces innovative HRM practices, the production worker will have more knowledge of options for correcting the problem (due to his higher training level), and he will have up-to-date information as to whether the current customer would reject such steel (given greater day-to-day information sharing). And perhaps most important, he will have easy access to other production workers and staff so that he can gather the necessary knowledge to solve the problem. For example, he may organize a group of people to help him solve the problem on the spot. In the organizational literature, the worker makes use of his "social network" of contacts to solve a specific problem.

Thus, problem-solving capacity is the capacity each individual worker has to solve problems by tapping into his co-workers knowledge base (or into his social network). More specifically, problem-solving capacity is reflected in the worker's connective capital, $\mathrm{CC}_{i}$, for worker $\mathrm{i}$ is equal to the sum of the communications between worker $\mathrm{i}$ and all other workers $\mathrm{j}$, weighted by the human capital knowledge, $\mathrm{HC}_{j}$, possessed by the worker with whom he communicates:

$$
\mathrm{CC}_{i}=\sum_{i} \sum_{i \neq j} \mathrm{cc}_{i j} \mathrm{HC}_{j}=\phi(\mathrm{HRM})
$$

Thus, when worker $\mathrm{i}$ has high connective capital, he communicates with others extensively. Note that to build connective capital or problem-solving capacity, the firm must implement innovative HRM practices, such as problem-solving teams, training, and incentive pay, that induce the communications and problem solving. Connective capital is a function of the innovative HRM environment, or $\phi(\mathrm{HRM})$ above.

Data on the individual communications patterns from the steel industry suggests that plants with more innovative HRM practices are raising their problem-solving capacity by increasing the communications network of their production employees. In Gant, Ichniowski, and Shaw (2002), we measure each worker's communications links with all other workers as they work on the job. On those steelmaking lines with innovative human resource management systems, workers interact with a majority of other line workers, both within shifts and across shifts. On those steelmaking lines with traditional human resource management practices, workers interact with a much smaller number of their peers or managers. 
Building Problem-Solving Capacity: The Complementarity of Innovative HRM

Practices and IT

Given the definition of problem-solving capital, the ways in which innovative HRM practices affect performance are twofold:

1. Innovative HRM practices raise the level of each individual's intellectual capital by providing employee with the information, training, and the opportunity to raise his or her level of intellectual capital.

2. Innovative HRM practices raise the level of each individual's problem-solving capital by providing employees with the access to their peers or manager's assistance, and by providing the incentive to utilize that access.

The innovative HRM practices of teamwork, information sharing, job rotation, and careful selection are aimed at reshaping a production worker from one who merely operates a machine to one who makes day-to-day and long-run decisions regarding the use of the machinery and the strategic capabilities of the machinery and the firm. Innovative HRM practices give workers the opportunity and the incentive to invest in problem-solving capacity, and then to make use of it as worker make day-to-day and long-run decisions regarding the use of the machinery and the strategic capabilities of the machinery and the firm. Firms reward the employee for these investments and higher effort levels, where the rewards could be in the form of either incentive pay or enhanced recognition and job satisfaction.

As this discussion implies, the various HRM practices tend to be complements greater use of one HRM practice will tend to increase the return to the others. In research on the steel industry, Ichniowski, Shaw, and Prennushi (1997) conclude first that the preponderance of evidence suggests that a full set of innovative HRM practices raises workers' performance levels more than does the adoption of individual practices. Then, using data from the survey of workers' communications patterns in a subset of these mills, Gant, Ichniowski and Shaw (2002) conclude that connective capital rises with innovative HRM practices. While that data cannot show that sets of complementary practices raise communications more than do individual practices, the overall body of research suggests that systems of HRM practices are more effective than individual practices. 
Other researchers have pointed out that IT and organizational changes or innovative HRM practices are complements (Breshnahan, Brynjolfsson, and Hitt, forthcoming, Black and Lynch, 2001). The likely reasons for the complementary nature of HRM and IT were given above - IT provides the information needed for better or faster problem-solving. In addition, the introduction of more innovative HRM practices to make better use of IT innovations.

In sum, firms today are likely to have a much greater incentive to invest in problem-solving capacity, and innovative HRM practices and IT investments are likely to contribute to their ability to invest. One key HRM practice to support building problemsolving capacity is the change in job design—broader job definitions (so workers do a greater range of tasks) and a flatter, less hierarchical, job structure, provide worker with the access to the information that builds problem-solving capacity. In recent literature, economists have emphasized either the importance of job design (Holmstrom and Milgrom, 1991) or the importance of the information network (Aoki, 1986, and Bolton and Dewatripont, 1994, Appelbaum and Berg, 1998, and Greenan and Mairesse, 1999), but have not combined these in the development of problem-solving capacity.

Overall, innovative HRM practices are aimed at raising the level and the incentive to develop knowledge capital by all employees. Most importantly, the uniqueness of my use of the term "problem-solving capital" is that it incorporates the value of production workers or other similar employees who would not be considered the star performers in a firm.

\section{The Effects of the IT and HRM Technology Shocks: Changes in Performance}

There are two sources of econometric evidence: industry specific studies; case studies of particular firms, and broad survey of firms across industries. The steel industry study is described first, to provide an in-depth account of the impact of HRM practices. 


\section{Has Increased Use of New Human Resource Management Practices Improved}

\section{Business Performance in the Steel Industry?}

Two primary studies, one based on data from finishing lines in integrated steel mills (mills that use basic oxygen blast furnaces; Ichniowski, Shaw and Prennushi, 1997) and one based on data from rolling lines in steel minimills (mills that use electric arc furnaces; Boning, Ichniowski and Shaw, 2002) provide evidence on performance effects. The first study uses panel data from 36 finishing lines which coat and treat very large coils of flat-rolled steel. The second study uses panel data from 34 minimill production lines that reheat very large steel beams and thin and shape the steel into thinner rods or bars for use in construction or manufacturing applications. Both studies include almost all of the production lines of these types in the United States, and develop large panels with well over 2,000 monthly observations in each study's sample.

The first study, of integrated steel finishing lines, concludes that systems of innovative human resource management practices are more effective in raising productivity than are the more traditional human resource management practices (Ichniowski, Shaw and Prennushi, 1997). Regression results suggest that productivity is 6.7\% higher under the most innovative human resource management system, 3.2\% higher under the "high teamwork" system, and 1.4\% higher under the "communications" system. Lines that adopt a full bundle of innovative work practices therefore achieve the highest levels of productivity and the traditional system the produces the lowest performance.

The second study, of minimill production lines, reinforces the finding that innovative human resource management practices improve productivity, but also highlights the complementarity between problem solving teams and incentive pay (Boning, Ichniowski, and Shaw, 2001),. Problem-solving teams are only adopted when incentive pay is already in place, and teams raise the return to incentive pay.

Intra-Industry and Cross-Industry Analyses of HRM Effectiveness 
The research method utilized in the steel industry studies has been labeled "insider econometrics," and to some degree this methodology has been utilized in other intra-industry studies of the effects of human resource management practices on business performance. The insider econometrics methodology is an approach in which economists go inside firms within one industry and gather data on performance and practices so that they are best able to model the production function within that industry and to measure HRM practices without error (Ichniowski and Shaw, 2003). As described in Table 2, in the apparel, auto, machine tool industries, and in call centers, there is evidence within and across plants that innovative HRM practices raise performance. Corroborating this intraindustry evidence is survey evidence from plants or firms. For the most part, the surveys regression results also show that innovative practices raise performance when adopted see Table 2.

Researchers in a number of European countries have had access to firm or establishment level data concerning HRM practices and performance. As in the U.S. studies, two main themes documented in intra-industry studies continue to gain support in these nation-wide, cross-industry analyses of human resource management practices and economic performance. First, firms tend to use multiple human resource management innovations. Second, new work practices, and more specifically interactions among new work practices, are associated with higher business performance. Overall, these conclusions apply for research for Denmark (Eriksson, 2001), Italy (Leoni, Cristini, Labory, and Gaj, 2001) Great Britain (Fernie and Metcalf, 1995; Michie and Sheehan, 1999; Millward, Bryson, and Forth, 2000), France (Ballot, Fakhfaky, and Taymaz, 2002; Greenan and Guellec, 1998; Greenan and Mairesse, 1999); and Germany (Wolf and Zwick, 2002). A summary of these papers is provided in Appendix Table B.

\section{$\underline{\text { Summary }}$}

In an earlier review of the effectiveness of innovative HRM practices, Ichniowski, Kochan, Levine, Olson, and Strauss (1997) conclude that the preponderance of evidence suggests that there are significant performance gains from managerial improvements in HRM, gains that outweigh the costs of these investments. Their conclusion is consistent with two studies of the productivity gains from innovative HRM 
practices in the steel industry. These steel studies, and the additional studies in other industries and across industries using survey data, reach the conclusion overall that innovative HRM practices are productivity enhancing. Moreover, a majority of these studies also reach the conclusion that sets or systems of complementary HRM practices tend to be productivity enhancing. While it is very difficult to econometrically prove that these HRM practices are complements (Athey and Stern, 2001), the preponderance of quantitative and qualitative evidence suggests that such complements exist (Pfeffer, 1995).

In the last few years, researchers have begun to emphasize the interaction between HR and IT, or that value that organizational changes have in enhancing the value of IT. Discussions of the complementarities between these practices are emphasized in Brynjolfsson and Hitt (2000) and Breshnahan, Brynjolfsson and Hitt (forthcoming) as they provide an explanation for the recently growing returns to IT investment: for these investments to payoff, firms must also invest in organizational changes. Other researchers making this point include: Autor, Levy, and Murnane (1999, 2001, 2001), Black and Lynch (forthcoming), Dunlop and Weil (1996), and Hunter and Lafkas (1998), and Shaw (forthcoming).

\section{Investing in Innovative HRM Practices - Should All Firms Invest?}

Thus far, I have emphasized the growing importance of investing in problemsolving capacity - to compete in international markets, and to utilize the U.S. comparative advantage in investing in human capital and information technologies. In reviewing the empirical results on the effectiveness of HRM practices, I conclude that these practices seem to raise worker performance levels, and thus that firms seem to be benefiting from their investments in HRM practices that produce higher levels of problem-solving capacity. But should all firms invest in innovative HRM and thus in greater problem-solving capacity? 


\section{Who Should Invest in HRM?}

The average firm should find it increasingly advantageous to make problemsolving investments, for three reasons: on average, product quality has gone up over time in the U.S. and innovative HRM practices are aimed at producing higher quality products; information technology use has gone up over time, and IT and problem-solving capacity or HRM practices are likely to be complements. And finally, as firms continue to discover the value of the HRM "technology shock," firms should raise investments in these practices independent of changes in product quality or IT.

However, like all investments, the investments in innovative HRM practices certainly have different rates of return across firms and not all should invest heavily in them. The minimill steel study provides the most "microeconomic" evidence on what types of firms ought to adopt. In that study, Boning, Ichniowski, and Shaw estimate a two equation model: one equation estimates the expected gains (or productivity gains) from investing in innovative HRM choices, and the other equation estimates the decision to invest in innovative HRM practices as a function of the characteristics of the technology. The econometric results show that the steel mills that gain the most and adopt the most innovative practices are those with more complex production lines and more complex high-quality products. This result is intuitively appealing: problemsolving is more valuable when the production environment faces greater problems due to its greater complexity or when output must be of the highest quality. In other words, firms that produce commodity products and that change their processes little over time will have the least to gain from investing in problem solving. However, other case study analysis in other industries (Bartel, Ichniowski, and Shaw, 2001) shows that firms that produce commodities may well find innovative practices to be valuable, if the production environment is highly capital intensive and high-quality, so both extensive IT and innovative HRM are valued.

This industry-specific evidence on the value of problem-solving is quite consistent with the survey correlations. Osterman (1994) concludes for his establishment survey (described in the next footnote) that plants that are more likely to adopt innovative 
team practices are those that are in an internationally competitive product market, have a technology that requires high skill levels, and that follow a strategy that emphasizes product quality and service rather than low costs. Ichniowski and Shaw (1995) also find that adoption is greater in steel mills that face more competitors. These factors are likely to be correlated with the expected productivity gains, but perhaps also with transition costs as well, because these costs are likely to be lower for newer plants.

Other researchers have emphasized the value of adopting innovative HRM practices to complement investments in IT - implying that firms that are high IT users are also likely to invest more in innovative HRM practices. Milgrom and Roberts (1990) describe cases of HRM and IT complementarity, such as Ford's joint adoption of computerized CAD/CAM design techniques along with a team approach to design and manufacturing. Appelbaum, Bailey, Berg and Kalleberg (2000) and Dunlop and Weil (1996) emphasize that the adoption of "modular" apparel manufacturing (which relies on a set of innovative human resource management practices) was driven by the implementation of computer-aided information systems used to track sales by large retailers. Finally, several recent studies using nation-wide, cross-industry business surveys find higher performance among businesses that adopt both innovative work practices and some computer technologies. (Brynjolfsson and Hitt, 2000; Bresnahan, Brynjolfsson and Hitt, 2002, forthcoming; Black and Lynch, 1997, forthcoming; Barua and Mukhopadhyay, 2000).

Thus, if IT raises the return to HRM practices, then the greater investments in IT over the last twenty-five years could contribute to the greater adoption of innovative HRM practices. Overall, these studies suggest that the use of IT and HRM may be complements because that IT raises the return to HRM by providing the technology to facilitate decision-making, and that HRM changes enable workers to make the best use of the investments in IT.

Though investments in IT may increase the value and use of innovative HRM practices, many firms may adopt HRM practices alone - without investments in IT. 
Several intra-industry studies summarized above - in the steel and auto assembly industries, for example - estimate significant returns to HRM practices in environments when IT investments are not growing substantially. For example, in the steel industry samples, while there is a modest positive cross-sectional correlation between measures of computerization and the use of innovative human resource management practices, there is no correlation between investments in new computer technology and the adoption of human resource management practices within mills over time. Interviews with managers also corroborate the conclusion that new human resource management practices were innovations aimed at raising performance undertaken independently of technology investments.

\section{Why Don't More Firms Invest in HRM?}

While differences across firms or plants in the long-run value of innovative HRM practices may explain much of the limited adoption of these practices, there may also be transition costs that limit adoption. While 93\% of large firms have some form of teamwork (Lawler, Morman, and Ledford, 1999), only about 40\% of all establishments use teams extensively for more than half of the work force (Osterman, 2000).

Transition costs associated with HRM adoption can be extensive and are examined in numerous studies. There are some obvious sources of transition costs. First, workers and managers must invest in entirely new skills - workers in decision-making skills and managers in 'coaching' or advisory skills as opposed to supervisory skills. Workers and firms may be slow to undertake these investments, even when there are performance gains to the actual use of innovative HRM practices, if the time horizon is short for the firm or for the workers. In addition, older firms, with investments in older HRM or IT technologies are earning rents on these investments. They undertook investments in old skills in the past, and as long as they can stay in the market and cover marginal costs, it may not be optimal to reinvest. These firms can compete with new firms, having higher average costs due to the costs of new HRM or IT, by earning rents on old investments. 
Second, complementarities between HRM practices can raise transition costs. Systems of innovative human resource practices should be adopted at once to raise performance, and in some industries, systems of innovative human resource management practices must be coupled with other management policies to improve performance (such as the use of production and inventory management policies in auto assembly plants; MacDuffie, 1995). Adoption of systems, rather than individual practices, makes the upfront costs more sizable. Since these costs are typically paid for out of retained earnings, investments may decline. Moreover, when systems of practices are most valuable, firms will find it more difficult to search for the optimal practices. Levinthal (1997) uses simulations to show that businesses might get "locked in" to an existing set of organizational policies that produce less than the highest levels of performance when complementarities exist among the organizational policies. Managers who begin with an inherited set of human resource management practices may search for better policy choices by experimenting with changes in only one or two policy areas. When broader complementarities exist among a large number of policies, performance will not improve and managers may then abandon their search for better practices. This kind of costly search would limit the adoption of innovative work practices.

\section{Changes in Labor Demand: Building Problem-Solving Capacity}

The innovative practices listed above contain some direct and indirect evidence on the ways in which innovative HRM practices affect labor demand. Regarding the direct ways in which it affects labor demand, one of the innovative HRM practices is the more careful screening of employees to select better employees. But what kind of employees are being selected?

The overall set of HRM practices described above can be used to indirectly infer the kind of employees the firm now demands in the problem-solving environment. Employees are expected to work in a team environment, to work smarter and to work harder, and to take greater responsibility in their day-to-day decision-making. To achieve these goals, the personal traits that firms seek in hiring workers are that they have the "team skills" to cooperate and communicate well with others in a team setting, the 
personal motivation and drive to respond to reward incentives such as pay and recognition; and the desire to take on additional responsibility (perhaps in response to better rewards). Overall, firms want employees with a "can do" attitude or the desire to make a difference.

Data from Black and Lynch (1996) and Holzer (1996) suggest that firms do search for workers with these personal and interpersonal skills. Black and Lynch provide survey evidence on hiring criteria using an extensive establishment survey conducted in 1994. They asked establishments to rank on a scale of 1 to 5 (5 most valuable) the a list of criteria in hiring, with the following mean outcomes (1996, page 266):

$\begin{array}{ll}\text { Applicant's attitude } & 4.6 \\ \text { Communication skills } & 4.2 \\ \text { Work experience } & 4.0 \\ \text { Outside recommendations } & 3.4 \\ \text { Industry credentials } & 3.2 \\ \text { Years of education } & 2.9 \\ \text { Employer tests } & 2.5 \\ \text { Applicant school grades } & 2.5\end{array}$

As is evident, the applicant's attitude, communications skills, and experience are considerably more important than education. Data from Holzer (1996) also directly summarizes skill needs. Holzer did a survey of U.S. establishments in four major U.S. cities and asked about the types of workers they seek in new hires. He found the following results by occupation for expected daily tasks to be performed: 
Occupation

$\begin{array}{lccccc}\text { Task } & \text { Prof/Man. } & \text { Clerk/Sales } & \text { Service } & \text { Craft/Oper. } & \text { Laborer } \\ \text { Customers } & 80 \% & 84 \% & 78 \% & 41 \% & 31 \% \\ \text { Read } & 88 \% & 67 \% & 58 \% & 54 \% & 34 \% \\ \text { Math } & 76 \% & 70 \% & 52 \% & 62 \% & 53 \% \\ \text { Computers } & 66 \% & 75 \% & 23 \% & 23 \% & 17 \%\end{array}$

(where "customer" is dealing with customers, read and math are the uses of reading or writing and arithmetic, and "computers" is the use of computers). Holzer was asking about the daily tasks on jobs, to ascertain the skills required by employers of their new hires. As a result of these tasks, he finds that firms demand fairly extensive skills or experience for most jobs; only $3 \%$ of all jobs have virtually no requirements. On average, about $50 \%$ of all jobs require some computer use, and this is similar to that reported in other studies (see Kreuger, 1993).

The next question is, has skill demand changed over time to emphasize the growing need for these problem-solving or people skills? There is no detailed time series data on task use, but Holzer does ask about changes over time and estimates that, on average, all the tasks above experienced by about 23-25 percentage point increase from 1980 to 1994. Thus, computer use rose, as did the importance of basic skills that are necessary in firms that require more employee involvement or more employee autonomy. ${ }^{2}$

There is a perception that in the new economy, the key skills that are needed are computer skills, but in surveys of firms, they rarely emphasize the importance of computer skills. They state that computer skills are fairly easy to teach on the job, but basic skills are not readily taught.

Finally, Autor, Levy, and Murnane (2002) provide a very comprehensive assessment of changes in skill demand over time. Using CPS data and information on required skills from the Dictionary of Occupational Titles to show that the demand for non-routine cognitive skills has risen over time. Moreover, this increase in cognitive skills is correlated with the use of new technologies. In a different study, that identifies the underlying skill distribution of workers, Abowd, Haltiwanger, Lane, and

${ }^{2}$ Of course, computer use alone could have caused the increases in the demand for other skills if computer users must undertake more skilled tasks. 
Sandusky(2001) also show that Industry studies, containing detailed descriptions of hiring changes in work places that adopt new technologies, add corroborating evidence of a connection between new work practices and an increased demand for problem-solving skills (Bartel, Ichniowski, and Shaw, 2001, Autor, Levy, and Murnane, 2001, Appelbaum, Bailey, Berg, and Kalleberg. 2000; Holzer, 1996).

\section{Policy Implications}

The description above of the changing demand for labor skills has numerous implications for public policy. First, the typical firm that is investing in innovative HR practices wants a worker who can think for himself, solve mechanical problems, participate in teams, communicate well, is responsible and reliable, and has a "positive attitude" towards hard work and rewards. Thus, I turn to policies that facilitate the development of such workers. Secondly, the typical firm that is utilizing innovative HRM practices is making an investment, and thus firms making those investments and earning returns to those investments should be rewarded - through higher stock market valuations. Thus, I turn to a consideration of how firms value these investments and are rewarded for these investments.

\section{The Investment in Human Capital: Education}

As described in Carneiro and Heckman (2002), the rate of return to education, as measured by income gains from education, tends to fall with increases in education - the return is highest for pre-school or early elementary and falls over time (see their Figure 61). This means, for example, that programs to improve the skills of high school dropouts are rarely successful, from a cost-benefit basis. High school dropouts may choose to complete high school by passing a series of tests to receive their high-school equivalent degree, called a GED. Though about 15 percent of all high school degrees granted today are GED degrees, the research shows that those achieving a GED do not earn higher wages than high school dropouts who have the same basic ability. Similarly, the income gains from post-school training, such as job training programs, are lower than the gains from pre-school educational investments per dollar invested. Therefore, when compared 
with the opportunity cost of investing, it is clear that optimal investment levels are very high for early education and fall from thereon.

The studies reviewed in the sections above of the value of innovative HRM practices and changes in skill demand provide a ready interpretation for the Carneiro/Heckman conclusion. The skills that tend to be taught in the early years - such as reading, math, communications, interpersonal relations, and motivation - are those skills that are particularly valuable in firms with innovative HRM practices. Moreover, studies in child development emphasize that there are lifecycle patterns to effective learning, and that cognitive skills are best taught early in the educational lifecycle (Carneiro and Heckman, page 27). These are the general skills that are very valuable and that are very difficult to teach later in life. Thus, it is early childhood interventions of high quality - such as the Perry Preschool program - that have permanent effects on learning and that raise incomes (Carneiro and Heckman, page 46). Note also that the often stated quote - "good families produce good children" - also implies that programs aimed at family or parental support often have indirect benefits in raising the quality of the children and their educational outcomes.

In addition, as emphasized in the labor demand discussion above, and by educational researchers, there are also important returns to investments in non-cognitive skills, such as motivation, dependability, or interpersonal communications that firms value. Some non-cognitive skills, such as motivation, are readily taught later in life through, for example, mentoring programs. But many programs inadequately address the need for these non-cognitive skills. The GED emphasizes cognitive testing to receive the high school diploma, but Carmeron and Heckman (1993) demonstrate that dropouts who move on to get their GED are those who have poor non-cognitive skills - they lack the ability to think ahead or to persist in tasks - and these skills are not developed by the GED program.

In sum, low-cost ways of increasing educational levels, such as the GED program or other forms of remedial training, are less likely to be effective than improvements in early education. Moreover, the returns to investment in early education are often 
estimated to be in the range of 17-20 percent (Carneiro and Heckman, page 23), which is higher than typical returns to the investment in physical capital. However, when training is provided later in life, returns to investment in non-cognitive skills are likely to be higher.

Recent patterns of investment in education have produced greater investment in higher education and less in elementary education. The investments in "basic skills" are declining over time in the U.S., and there is increasingly a bimodal distribution to investments in human capital overall. ${ }^{3}$ Once GED degrees are subtracted from the measure of annual high school graduation rates, the numbers of high school graduates is trending down over time. The U.S. is now producing a greater fraction of low skill dropout youth than it was thirty years ago, even though it is these basic skills that are necessary to obtain the higher-wage higher-performing jobs even for the less educated workforce. Moreover, studies show that the demographic groups that have increased their educational levels in recent years in response to higher wage returns to education are the groups that are predominately white middle income - youth coming from lower income households have been responding more slowly to the wage returns to education, and thus the income gap between households is growing.

\section{The Investment in Human Capital: Firms' Investment in Training}

Firms have long invested fairly significantly in the training of their workforces. However, the use of innovative HRM practices emphasizes two things: competency levels need to be higher than previously if production workers (or other less-educated workers) are going to do greater amounts of problem solving; and workers need to have a broader range of general skills that includes basic skills (math, reading) and communications and interpersonal skills.

Overall, firms are unlikely to teach basic skills to their employees for several reasons. First, the majority of training is of an informal nature, and thus would not

\footnotetext{
${ }^{3}$ Levy and Murnane (1995) make a strong case for the investment in basic skills that emphasize problem solving.
} 
produce basic skills training (Lowenstein and Spletzer, 1999). Second, most of the training dollars go to the better educated workers, who are learning how to do very specific jobs. Even among newly hired workers, most of the formal and informal training goes to those who are more highly educated (above high school). Thus, workers with more sophisticated tasks get more training, and these are workers who are already likely to have the necessary basic skills, such as math, reading, and verbal skills. Third, these basic skills are very "general" skills, that are not specific to the firm, and thus workers have every incentive to take their skills elsewhere to firms that will pay higher wages since they did not absorb the investment costs. When firms do train in skills that are valuable to other firms (and 70 percent of all firms believe that most of their training is in largely general skills, Barron, Berger, and Black, page 282), the skills tend to be very specific to the occupation, and not "basic" in nature. ${ }^{4}$

Overall, firms are unlikely to teach basic cognitive skills, like math and reading, but they do provide some training that is of a general nature. They do provide training in specific problem-solving methods (like "6-sigma") and communications skills. But such training is only effective if the workforce already has the basics skills, in math, reading, and non-cognitive motivational factors. Thus, the basic skills, that are likely to have the biggest returns in the labor market, must be taught in school. The evidence on hiring and screening patterns corroborates this conclusion: firms increasingly search for workers who have the basic skills, as described in the "Labor Demand" subsection above-they do not hire less-skilled workers and then train them.

\section{The Investment in Human Capital: Governmental Support for Investment in} Training

Governmental programs to facilitate the development of skills through postsecondary training are numerous. Beginning in the 1960s, the Job Corps and the

\footnotetext{
${ }^{4}$ For reviews of the training practices of firms, see Leuven and Oosterbeek (1999), Finegold and Mason (1999), Lowenstein and Spletzer (1999), Barron, Berger, and Black (1999), and Bishop (1997).
} 
Manpower Development and Training Act provided training for disadvantage youth and for technologically dislocated workers. By the 1970s and 1980s there was a shift towards helping disadvantaged workers (Comprehensive Employment and Training Act of 1973) and of involving the private sector in training (Job Training Partnership Act of 1982 and then the Workplace Investment Act in 1998). At the same time, there have been mandatory training programs for welfare recipients (the Work Incentive Program of 1967 for job search, and the JOBS program of 1988 for training and search). In 1996, the reform of the welfare system increased the emphasis on job training assistance. In sum, by 2002 , the federal government spent about $\$ 6$ billion a year on training programs.

States also invest fairly heavily in training, and often the training programs are aimed with working with specific employers, or providing vouchers to employers. Total spending is over $\$ 600$ million by 45 states, though $60 \%$ of this is done by just ten states. Most of the training is for incumbent workers, currently employed, and thus the programs tend to be tailored for the specific companies or occupations.

Are these training programs effective in raising the incomes of those who are trained? The evidence suggests that the programs are most effective when they are aimed at disadvantaged women or at dislocated workers (Carneiro and Heckman, and Economic Report of the President, 2001). It is much harder to reach disadvantaged youth, or men, with training or search to increase their incomes.

These results, on the limited effectiveness of training, are consistent with two arguments made above. First, early education is more effective than later training-rates of return to early education are higher than rates of return to investment in training, and early education is much more likely to help disadvantaged males. Second, the HRM studies would reach these same conclusions: those individuals who did not learn basic skills in school are very hard to "retrain" later in life. Firms value the basic skills on which to build - given basic skills, investments in specific skills are done within firms (both formal and informal investment in new skills). If individuals do not learn these basic skills early in life, it is very costly to teach them later, and without the basic skills, 
firms cannot train. Thus, training programs are more likely to be successful for women, who may have the basic skills but have not participated in the labor market in the past, or for dislocated workers, who clearly do have the basic skills. Welfare-to-work policies and other training programs are aimed today at working with firms to train new workers with the specific skills that are needed by firms. These programs are most likely to be effective when the participants in the programs have basic skills (reading, writing, communicating, and motivation) on which to build with new specific investments.

Note finally that the government is also indirectly influencing training through their tax or subsidy programs. Training is an expense that reduces pre-tax income for companies. Thus, in years in which firms have profits, investments in formal training are subsidized. However, the form of the subsidy for training differs from that of other investments by the firm, in physical capital or in R\&D. Physical capital is not expensed, but is depreciated over time, and $\mathrm{R} \& \mathrm{D}$ receives a tax credit (rather than a deduction) and thus R\&D expenditures reduce the firm's taxes dollar-for-dollar. As a result, in principle investments in training relative to these other investments may well vary with the business cycle - rising in booms to take advantage of the tax reduction - and are less heavily subsidized. However, these indirect tax subsides for training are likely to have little effect on training expenditures, for three reasons. First, because investments are made from retained earnings (not by borrowing as is true for capital expenditures) they will tend to vary with the cycle without the tax effects. Second, the tax effects refer only to investments in formal training programs, which are likely to be considerably smaller than investments in informal training on the job. And investments in informal training may rise during recessions, when the opportunity cost of time for workers falls. Finally, when looking across firms, at which firms train and which don't, the differences in training are likely to arise from differences in the production function for firms, rather than tax differences-some firms get much higher basic returns to training than others. Of course, because firms can expense the costs of training, there is un underlying subsidy in favor of training investments by firms as opposed to investments by individuals (such as full-time college) that are not subsidized (except through loan programs). 


\section{The Investment in Human Resources: Valuing the Investment}

The adoption of innovative HRM practices is described repeatedly above as in "investment" in response to the technology shocks-where the shocks of innovative HRM, IT shocks (or falling IT prices), and rising emphasis of on quality (perhaps due to rising value of the dollar) induce greater investment in HRM. The cost side is comprised of the costs of training, of carefully screening workers, of sharing information, of initiating and maintaining a formal team structure, of structuring compensation appropriately, and of maintaining a degree of employment security. The returns come over the long run, through higher performance and higher profits.

Unlike the investments in physical capital or research and development, firms typically do not measure their investments in human resources. Most firms do not know how much they spend on training - on either formal or informal training programs. In annual reports for GAAP purposes, firms would include their training expenditures as a hidden part of their selling, general, and administrative expenses. Only when training exceeds a "material" amount (generally 5 percent of revenues) would it be reported as a separate line item, and few firms spend that much. Firms are even less likely to measure the more intangible investments in other human resource practices. And lastly, they are least likely to assess whether these investments earn returns. When corporate managers are asked whether there would be significant benefits to having better information about their investments, $70 \%$ say there would be, and also say that financial investors would value that information (Bassi, Lev, Low, McMurrer, and Siesfeld, 2002).

However, while firms often say that they wish to have better valuation for such intangible assets such as these: "we currently have no formal measure of knowledge assets, but these assets are our survival assets, and the most strategic for our long-term viability." (Ron Soler, Lockheed Martin Corp, in CFO.com 4/10/2003). And assets such as these "do not get reflected on our balance sheet" (Brad Goodwin, Genentech, CFO.com). Finally, Kaplan concludes that "Managing knowledge capitl will be critical for organizations to create a sustainable, competitive advantage." 
Valuation systems are increasingly proposed, but it is difficult to develop a measurement system that would be broad based and generalizable, so that data can be compared across firms. There are many suggestions for such valuations, and some have been implemented. For example, the "Balanced Scorecard" is one method of valuing intangibles like human resources within firms that is widely adopted by many firms. ${ }^{5}$ Lev (2002) develops a concept of "structural capital" that represents the organizational capital-like technologies, managerial processes and designs - that enables firms to profit from the investments in both tangible and intangible capital (like training). But again, it is difficult to measure - he imputes it for each firm from sales and expenditure data and shows that, while it is correlated with stock market returns, there also appears to be room for improvements in stock market efficiency by providing more information on intangible capital. ${ }^{6}$ Note, however, that another study has found that firms investment in HRM practices are correlated with stock market returns (Lev, 2002) - showing that stock market investors are of course taking steps to impute value to firms when they make investments in intangible assets.

Overall, firms do not have the incentive to develop systematic accounting framework for valuing intangible capital, nor do they have the incentive to share their own information with others. Firms do have some incentive to invest in the measurement of intangibles - to allocate internal resources and to signal to investors - but the full returns to developing systematic (across firm) reporting methods do not accrue to individual firms. Thus, that leaves the government sector to consider a role in the development and disclosure of such an information structure.

\section{Conclusion}

There is now an increasingly large body of empirical research, based on data from firms or within plants, that reaches the conclusion that investments in innovative HRM practices raise workers' performance levels. These practices - such as teamwork,

\footnotetext{
${ }^{5}$ See Kaplan and xx $(1996,2001)$ and Huselid and Barnes (2002) emphasize its use in HRM applications.

${ }^{6}$ See also Hall (2000a, b), Nakamura (1999), Lev (2001), and FASB (2000) for suggestions for voluntary disclosures.
} 
information sharing, training, careful screening and hiring, job rotation, employment security, and incentive pay - are often adopted jointly by firms to form complementary systems of HRM practices that enhance performance. These systems of innovative practices seem to be aimed at building the development and use of the problem-solving capacity of the workforce.

Given this microeconomic evidence, two questions remain-what firms gain the most from investments in HRM practices, and have these practices contributed overall to the productivity gains for the macroeconomy in the last five years? The empirical evidence suggests that the firms that gain the most from innovative HRM practices are either those that produce high-quality or highly complex products, or those firms that are also making investments in new information technologies. Both environments are likely to benefit from the greater problem-solving skills and incentives that innovative HRM practices generate.

There is some indirect evidence that suggests that innovative HRM practices may well be contributing to the productivity gains of the economy overall. Of course, the conclusion that many firms gain, based on micro evidence, suggests that the macroeconomy gains as well. However, there is indirect evidence of macroeconomic gains. Over the last twenty-five years, the distribution of wages has become more skewed-the numbers of people in the bottom of the wage distribution has grown, and the numbers in the top have grown. Most important for the analysis of HRM effectiveness, the wage distribution has become more unequal even within very narrowly defined industries and occupations (Autor and Katz, 1999). Thus, even among workers with very homogeneous measured skills, such as blue collar workers with high school degrees within detailed manufacturing industries, the variance of wages has risen. What could account for this rising variance? A portion of it is due to changes in institutions the decline of unions and the minimum wage-and these caused the greatest increase in inequality in the 1980s (Card and DiNardo, 2002). However, the unexplained rise in the variance over the entire 1980-1990's period may well represent rising returns to intangible skills, such as problem-solving or communications or motivation (see Autor, 
Levy, Murnane, 2003, for evidence supporting this view). These vary intangible skills are those that are supported or developed through the use of innovative HRM practices within firms. Thus, the higher wages paid to attract and retain workers with these intangible skills are likely to reflect the higher performance gains achieved by employing highly skilled workers and managing them with innovative HRM practices. These workers, and supporting HRM practices, enable firms to achieve competitive advantage through information technologies and a focus on innovative high-quality products and processes.

There are two sets of potential government policies that support the sustained use of innovative HRM practices as a productivity driver. First, the investment in basic education, in reading, math, and problem solving at the elementary and secondary level is a public good that earns long run returns in the U.S. and that enables firms to utilize innovative HRM practices that require workers with these basic skills. Second, firms and markets are now placing greater value on the returns to firm-level investments in intangibles, such as innovative HRM practices, and there is certainly room for improvement in the accounting standards for valuing these investments. 


\section{References}

[1] Abowd, John, John Haltiwanger, Julia Lane, and Dristin Sandusky (2001). "Within and Between Firm Changes in Human Capital, Technology, and Productivity." Working paper.

[2] Abowd, John, John Haltiwanger, and Julia Lane. "From Workshop Floor to Workshop Clusters," Report to the Alfred P. Sloan Foundation, 2002.

[5] Appelbaum, Eileen, Thomas Bailey, Peter Berg, and Arne Kalleberg (2000). Manufacturing Advantage: Why High-Performance Work Systems Pay Off. Ithaca, NY: Cornell University Press.

[6] Appelbaum, E., T. Bailey, P. Berg and A. L. Kalleberg (2000). Manufacturing Advantage Why high-performance work systems pay off. Ithaca, NY: Cornell University Press.

[7] Athey, Susan and Scott Stern (1998). "An Empirical Framework for Testing Theories about Complementarity in Organizational Design," working paper, NBER.

[8] Athey, Susan and Scott Stern. "the Impact of Information Technology on Emergency Health Outcomes," Working paper, MIT, 2000.

[9] Autor, David, Frank Levy, and Richard Murname (2001). "The Skill Content of Recent Technological Change: An Empirical Investigation.”

[10] Autor, David, Frank Levy, and Richard Murname (2001). "Upstairs Downstairs: Computers and Skills in Two Floors of a Large Bank."

[11] Autor, David, and Lawrence Katz (1997). “.” Quarterly Journal of Economics.

[11] Baily, M. N. "Information Technology and Productivity: Recent Findings," Institute for International Economics. Presentation at the AEA Meetings, January 3, 2003.

[12] Baily, M. N. "Macroeconomic Implications of the New Economy," Institute for International Economics. Working paper.

[13] Ballot, G., F. Fakhfakh and E. Taymaz. (2002) "Who benefits from training and R\&D: The firm or the workers? A study on panels of French and Swedish firms," Working paper.

[14] Bartel, Ann (1995). "Training, Wage Growth, and Job Performance: Evidence from a Company Database," Journal of Labor Economics, vol. 13, no. 3, pp. 401-425.

[14] Barron, John, Mark Berger, and Dan Black. (1999). "Replacing General with Specific Training," Research in Labor Economics, 18: pp. 281-302.

[15] Bartel, Ann, Casey Ichniowski, and Kathryn Shaw (2001). "New Technology, Human Resource Practices and Skill Requirements: Evidence from Plant Visits in Three Industries."

[15] Bassi, Laurie, Baruch Lev, Jonathan Low, Daniel McMurrer, and G. Anthony Siesfeld, "Measuring Corporate Investments in Human Capital," in Blair and Kochan, ed, pp. 334-369.

[16] Batt, Rosemary (1999). "Work Organization, Technology, and Performance in Customer Services and Sales," Industrial and Labor Relations Review, vol. 52, pp. 539-64. 
[17] Bauer, T. (2002). "Incidence and Labor Market Effects of High-Performance Work Practices in Germany." Working paper.

[18] Baura, Anitesh and Tridas Mukhopadhyay (2000). "Information Technology and Business Performance: Past, Present and Future," in Robert W. Zmud, editor, Framing the Domains of IT Management: Cincinnati, Ohio: Pinnaflex Educational Resources, Inc.: 65-84.

[19] Becker, Brian and Mark Huselid (1996). " Methodological Issues in Cross-sectional and Panel Estimates of the Human Resource-firm”, Industrial Relations, vol. 35, no. 3, pp. 400-422.

[20] Becker, B.E. and M.A. Huselid (1998). "High Performance Work Systems and Firm Performance: A Synthesis of Research and Managerial Implications," Research in Personal and Human Resources Management, 16, 53-101.

[21] Berg, Peter, Appelbaum, Eileen, Bailey, Thomas, and Kalleberg, Arne (1996). "The Performance Effects of Modular Production in the Apparel Industry." Industrial Relations 35: 356-73.

[21] Bishop, John. (1997). "What We Know About Employer Provided Training," Research in Labor Economics, 16: pp. 19-87.

[22] Black, Sandra and Lisa Lynch (1997). "How to Compete: The Impact of Workplace Practices and IT on Productivity," NBER Working Paper no. 6120.

[23] Black, Sandra and Lisa Lynch (May 1996). "Human Capital Investments and Productivity," American Economic Review Papers and Proceedings: vol. 86: 263-267.

[24] Black, Sandra and Lisa Lynch (2000). "What's Driving the New Economy: The Benefits of Workplace Innovation," NBER Working Paper no. 7479.

[25] Black, Sandra and Lisa Lynch (forthcoming). "How to Compete: The Impact of Workplace Practices and IT on Productivity," Review of Economics and Statistics.

[26] Blair, M. M. and T. A. Kochan (2000). The New Relationship: Human Capital in the American Corporation. Washington, D.C.: Brookings Institution Press.

[27] Board on Science, Technology and Economic Policy (1999). Securing America's Industrial Strength: U.S. Industry: Restructuring and Renewal. Washington, D.C.: National Academy Press.

[28] Boning, Brent, Casey Ichniowski, and Kathryn Shaw (2001). "Opportunity Counts: Teams and the Effectiveness of Production Incentives,” NBER Working Paper \#8306, May.

[29] Borghans, Lex, Weel, Bas ter, "Computers, Skills and Wages.” Working paper, May, 2001. Maastricht University.

[30] Bresnahan, Timothy, Erik Brynjolfsson and Loren Hitt (2001 forthcoming). "Information Technology, Work Organization and the Demand for Skilled Labor: Firm-Level Evidence," Quarterly Journal of Economics. 
[31] Brynjolfsson, Erik, and Loren Hitt. "Paradox Lost? Firm-Level Evidence on the Returns to Information systems Spending," Management Science, April 1996, 541-58.

[32] Brynjolfsson, Erik, and Loren Hitt (2000). "Beyond Computation: Information Technology, Organizational Transformation, and Business Performance," Journal of Economic Perspectives.

[34] Burgess, S. and P. Metcalfe (1999). "The Use of Incentive Schemes in the Public and Private Sectors: Evidence from British Establishments," CMPO Working Paper Series No. 00/15.

[35] Cappelli, Peter and David Neumark (1999). "Do High Performance Work Practices Improve Establishment-Level Outcomes?” NBER Working Paper no. 7374.

[35] Card, David and John DiNardo, 2002. "Technology and U.S. Wage Inequality: A Brief Look” Federal Reserve Bank of Atlanta Economic Review. Third quarter: pp. 45-62.

[36] Carneiro, P. (2002). "Heterogeneity in the Returns to Schooling: Implications for Policy Evaluation.” Working paper, University of Chicago.

[37] Carneiro, P. and J. J. Heckman (2002). "Human Capital Policy," Working paper, University of Chicago.

[38] Caroli, Eve and John Van Reenen (1998). "Human Capital and Organizational Change: Evidence from British and French Establishments in the 1980s and 1990s," Journal of Economic Literature.

[39] Chennells, Lucy and John Van Reenen (1998). "Technical Change and the Structure of Employment and Wages: A Survey of the Micro-Econometric Evidence," Journal of Economic Literature.

[40] Chun, H. and M. I. Nadiri (2002). "Decomposing Productivity Growth in the U.S. Computer Industry," NBER Working Paper Series.

[41] Cole, Robert E. (2000). "Market Pressures and Institutional Forces: The Early Years of the Quality Movement," in The Quality Movement and Organization Theory, eds. Robert E. Cole and W. Richard Scott (Sage Publications, Inc.: Thousand Oaks, CA), pp. 67-88.

[42] Computer Science and Telecommunications Board: National Research Council (1998). Fostering Research on the Economic and Social Impacts of Information Technology. Washington, D.C.: National Academy Press.

[43] Council of Economic Advisers (2001). The Economic Report of the President, 2001. Washington, D.C.: Government Printing Office.

[45] Dearden, L, H. Reed and J.Van Reenen (2000). "Who Gains When Workers Train? Training and Corporate Productivity in a Panel of British Industries," Working paper.

[46] DeLong, J. B. (2002). "Productivity Growth in the 2000's," Working paper University of California at Berkeley and NBER.

[47] Dunlop, John and Weil, David (1996). "Diffusion and Performance of Modular Production in the U.S. Apparel Industry." Industrial Relations 35: 334-54. 
[48] Engardio, P., A. Bernstein and M. Kripalani (2003). "The New Global Job Shift," BusinessWeek Online, The McGraw-Hill Companies.

[49] Eriksson, T. (2001). "The Effects of New Work Practices: Evidence from EmployerEmployee Data" paper presented at the International Conference on Organizational Design, Management Styles, and Firm Peformance, University of Bergamo.

[50] Eriksson, T. (2002). "How common are the new compensation and work organization practices and who adopts them?" Working paper.

[51] Eriksson, T. (2003). "The Effects of New York Practices - Evidence From EmployerEmployee Data," Elsevier Science, 7, 3-30.

[52] FASB, 2000, "Improving Business Reporting: Insights into Enhancing Voluntary Disclosures," Financial Accounting Standards Board, CT.

[52] Federal Reserve Bank of Atlanta Economic Review (2002). Economic Review, Third Quarter 2002, Volume 87, Number 3.

[53] Fernie, S. and D. Metcalf (1995). "Participation, Contingent Pay, Representation and Workplace Performance: Evidence from Great Britain," British Journal of Industrial Relations 33:3 September 1995: 378-415.

[53] Finegold, David and Geoff Mason. (1999). "national Training Systems and Industrial Performance: U.S.- European Matched-Plant Comparisons," Research in Labor Economics, 18: pp. 3331-358.

[55] Freeman, R. B. (2002). "The Labour Market in the New Information Economy," NBER Working Paper Series.

[56] Gant, Jon, Casey Ichniowski, and Kathryn Shaw, 2002 forthcoming. "Social Capital and Organizational Change in High-Involvement and Traditional Work Organizations," (with Jon Gant and Casey Ichniowski), Journal of Economics and Management Science.

[57] Gibbons, Robert (1998). "Incentives in Organizations," Journal of Economic Perspectives, Fall, 12(4): 115-132.

[58] Gittleman, Maury, Michael Horrigan, and Mary Joyce (1998). "Flexible Workplace Practices: Evidence from a Nationally Representative Survey," Industrial and Labor Relations Review, vol. 52, pp. 99-115.

[60] Greenan, Nathalie and Dominique Guellec (1997). "Firm Organization, Technology and Performance: An Empirical Study," Economic Innovation New Technology, vol. 6, pp. 313-347.

[61] Greenan, N. and J. Mairesse (1999). "Organizational Change in French Manufacturing: What Do We Learn From Firm Representatives and From Their Employees?” NBER Working paper.

[63] Hall, Robert (2002b). "e-capital: the Link Between the Stock Market and the Labor Market in the 1990s," working paper, Hoover institution and Department of Economics, Stanford University. 
[63] Heckman, J. J. (2002). "Flexibility and Job Creation: Lessons for Germany," NBER Working Paper Series.

[65] Holzer, Harry, What Employers Want: Job Prospects for Less-Educated Workers. New York: Russell Sage Foundation, 1996.

[66] Hubbard, Thomas, "The Demand for Monitoring Technologies: the Case of Trucking" Quarterly Journal of Economics, May 2000: 533-560.

[67] Huselid, Mark A. "The Impact of Human Resource Management Practices on Turnover, Productivity, and Corporate Financial Performance." Academy of Management Journal 38 (1995): 635-72.

[68] Huselid, M.A. and J. E. Barnes (2002). "Human Capital Measurement Systems as a Source of Competitive Advantage," Working paper.

[69] and Becker, Brian E. "High Performance Work Systems and Firm Performance: Cross-Sectional Versus Panel Results." Industrial Relations 35 (1996): 400-422.

[70] Ichniowski, Casey, Thomas A. Kochan, David Levine, Craig Olson, and George Strauss (1997). "What Works at Work: Overview and Assessment," Industrial Relations, vol. 35, pp. 299-333.

[71] Ichniowski, Casey (1990). "Human Resource Management Systems and the Performance of U.S. Manufacturing Businesses.” NBER Working Paper no. 3449.

[72] Ichniowski, Casey, John T. Delaney, and David Lewin (1989). "The New Human Resource Management in U.S. Workplaces: Is It Really New and Is It Only Nonunion?" Relations Industrielles, vol. 44, pp. 87-119.

[73] Ichniowski, Casey (1992). "Human Resource Practices and Productive Labor-Management Relations." In Research Frontiers in Industrial Relations and Human Resources, eds. David Lewin, Olivia Mitchelland Peter Sherer, Madison, Wisc.: IRRA, pp. 239-271,.

[74] Ichniowski, Casey and Shaw, Kathryn (1995). "Old Dogs and New Tricks: Determinants of the Adoption of Productivity-Enhancing Work Practices." Brookings Papers: Microeconomics 165.

[75] (1999). "The Effects of Human Resource Systems on Productivity: An International Comparison of U.S. and Japanese Plants" Management Science, 45: 704-722.

[76] (2000). "TQM Practices and Innovative HR Practices: New Evidence on Adoption and Effectiveness," in Robert Cole and Richard Scott, eds., The Quality Movement in America: Lessons from Theory and Research, New York: Russell Sage: 347-366.

[77] and Giovanna Prennushi (1997). "The Effects of Human Resource Management Practices on Productivity,” American Economic Review, 86: 291-313. 
[78] Jensen, Michael C. and William H. Mechling (1992). "Specific and General Knowledge and Organizational Structure," in Contract Economics, eds. Lars Werin and Hans Wijkander (Blackwell: Oxford), pp. 251-74.

[79] Jorgenson, D. W., M. S. Ho and K. J. Stiroh (2002). "Information Technology, Education, and Sources of Economic Growth across U.S. Industries," NBER Working Paper Series.

[80] Jorgenson, D. W., M.S. Ho and K. J. Stiroh (2002). "Lessons from the U.S. Growth Resurgence," Federal Reserve Bank of Atlanta Economic Review. Third quarter: pp. 1-14.

[81] Kandel, Eugene and Edward Lazear (1992). "Peer Pressure and Partnerships," Journal of Political Economy, vol. 100, pp. 801-817.

Kaplan, Robert, (1992) The Balanced Scorecard. Cambridge: Harvard University Press.

[82] Kelley, Mary Ellen, "Participative Bureaucracy and Productivity in the Machine Products Sector," Industrial Relations, vol. 35, pp. 374-399.

[83] Kochan, Thomas A., Harry C. Katz, and Robert B. McKersie (1986). The Transformation of American Industrial Relations. New York: Basic Books.

[84] Krafcik, John (1988). "Triumph of the Lean Production System", Sloan Management Review, vol 30, pp. 41-52.

[85] Kreps, David (1986). "Corporate Culture and Economic Theory." in Technology, Innovation and Business Strategy, ed. M. Tsuchiya. Tokyo: Nippon Keizai Shumbunsha Press.

[86] Lawler, Edward E., Susan A. Mohrman and Gerald E. Ledford Jr. (1995). Creating High Performance Organizations: Practices and Results of Employee Involvement and Total Quality Management in Fortune 1000 Companies San Francisco, CA: Jossey-Bass.

[89] Lazear, Edward (1995) Personnel Economics, Cambridge, MA: MIT Press.

[90] Lazear, Edward, "Performance Pay and Productivity," American Economic Review, December 2000, 90(5): 1346-1361.

[91] Leoni, Riccardo, Annalisa Cristini, Sandrine Labory, and Alessandro Gaj (2001). "New Work Practices in Italy: Adoption and Performance Effects" paper presented at the International Conference on Organizational Design, Management Styles, and Firm Peformance, University of Bergamo.

[91] Leuven, Edwin and hessel Oosterbeek. (1999). "The Demand and Supply of Work-Related Training: Evidence from Four Countries," Research in Labor Economics, 18: pp. 303-3330.

[92] Lev B. and S. Radhakrishnan (2002). “Structural Capital,” NBER Working Paper Series.

[92] Lev, B. (2001). Intangibles: Management, Measurement and Reporting, The Brookings Institution, Press, UK.

[93] Levine, D.I. (1998). Working in the Twenty-First Century: Policies for Economic Growth Through Training, Opportunity, and Education. Armonk, NY: M.E. Sharpe. 
[94] Levinthal, Daniel (1997). Adaptation on Rugged Landscapes." Management Science, vol. 43.

[95] MacDuffie, John Paul (1995). "Human Resource Bundles and Manufacturing Performance: Organizational Logic and Flexible Production Systems in the World Auto Industry," Industrial and Labor Relations Review, 48: 197-221.

[96] Mairesse, Jacques and Nathalie Greenan (1999). "Organizational Change and Productivity in French Manufacturing: What Do We Learn From Firm Representative and Their Employees?" NBER Conference on Organizational Change and Performance Improvement.

[97] Michie, J. and M. Sheehan (1999). "HR Practices, R\&D Expenditures and Innovative Investment: Evidence from the UK's Workplace Industrial Relations Survey," Industrial and Corporate Change, vol. 8, no. 2, pp. 211-233.

[98] Milgrom, Paul and John Roberts (June 1990). "The Economics of Modern Manufacturing." American Economic Review, vol. 80 (30), pp. 511-528.

[99] Milgrom, Paul and John Roberts (1995). "Complementarities and Fit: Strategy, Structure, and Organizational Change in Manufacturing," Journal of Accounting and Economics 19: 179208.

[101] Murnane, R.J. and F. Levy (1996). Teaching The New Basic Skills: Principles for Educating Children to Thrive in a Changing Economy. New York, NY: The Free Press.

[101] Nakamura, L (2000) "Intangibles: what Put the New in the New Economy." Federal Reserve Bank of Philadelphia, Business Review, July/August: 3-16.

[101] Oliner, Stephen and Daniel Sichel, "Information Technology and Productivity: where are we Now and Where are we Going?" Federal Reserve Bank of Atlanta Economic Review. Third quarter: pp. 15-44.

[102] Osterman, Paul (1994). "How Common is Workplace Transformation and Who Adopts It?" Industrial and Labor Relations Review 47, 2: 173-87.

[103] Osterman, Paul (2000). "Work Reorganization in an Era of Restructuring: Trends in Diffusion and Effects on Employee Welfare" Industrial and Labor Relations Review, vol. 53, pp. 179-196.

[104] Prendergast, Canice, "The Provision of Incentives in Firms," Journal of Economic Literature, March 1999, 37: 7-63.

[105] Sparrow, P. R. and J. Hiltrop. Chapter 19 - "Redefining the Field of European Human Resouce Management: a Battle between National Mindsets and Forces of Business Transition?"

[107] Wolf E. and T. Zwick (2002). "Reassessing the impact of high performance workplaces," Working paper. 


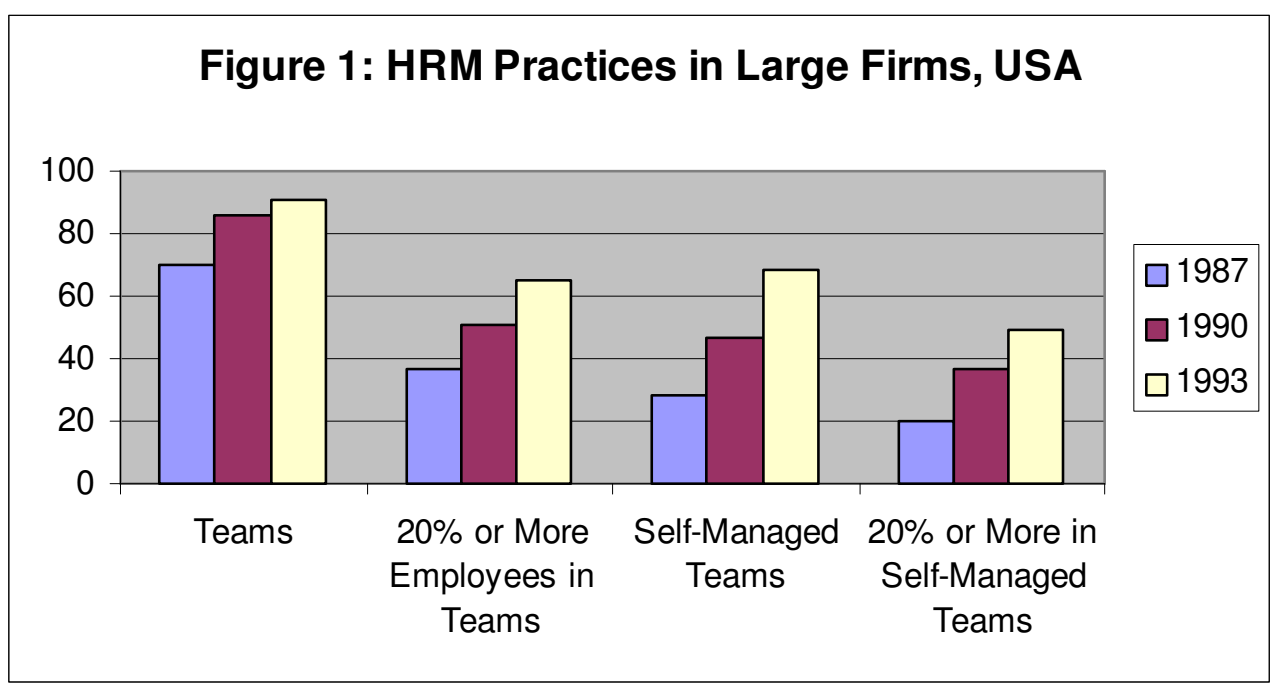

Source: Lahler, Mohrman, and Ledford (1995) 
Figure 2

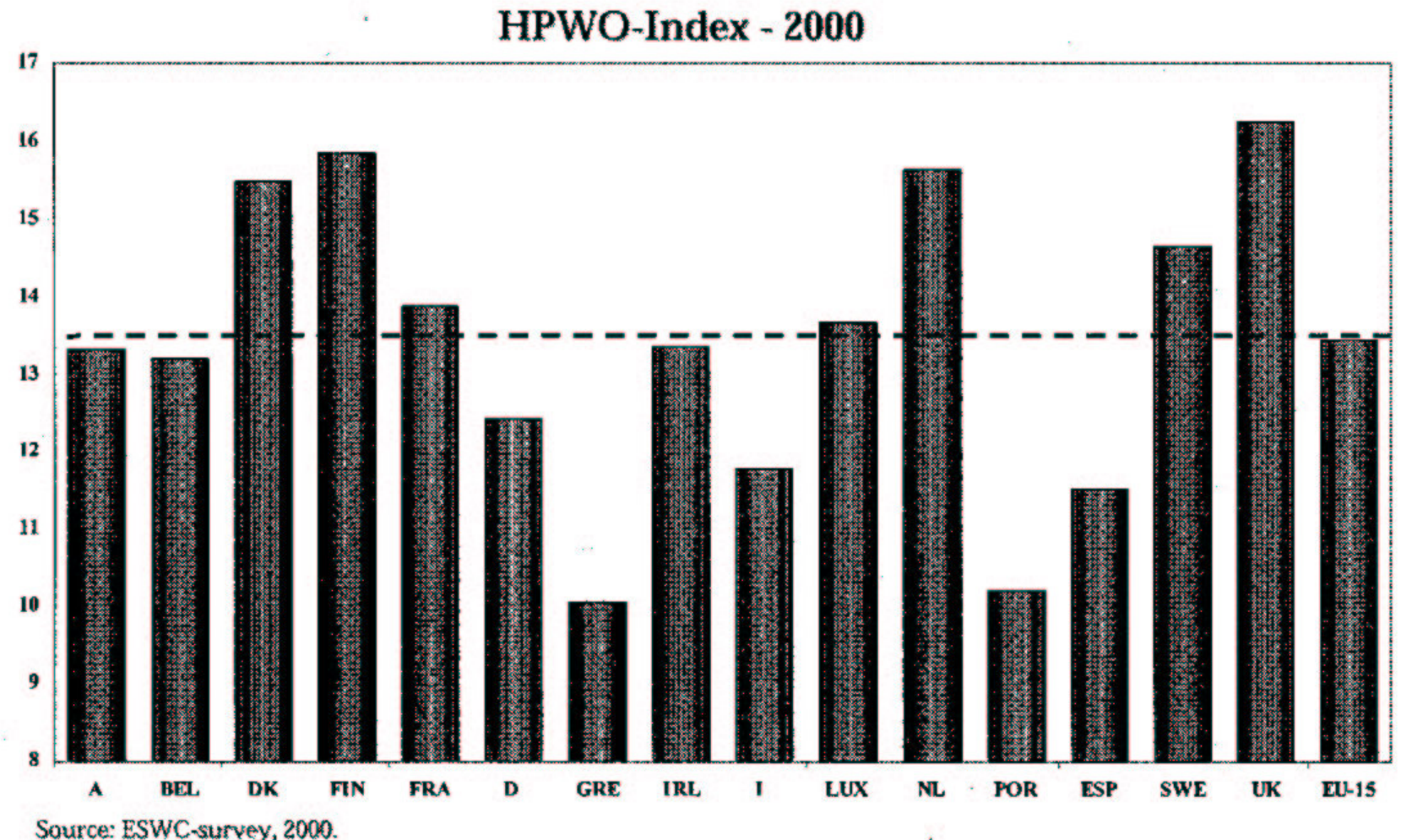

Source: Bauer (2002) 


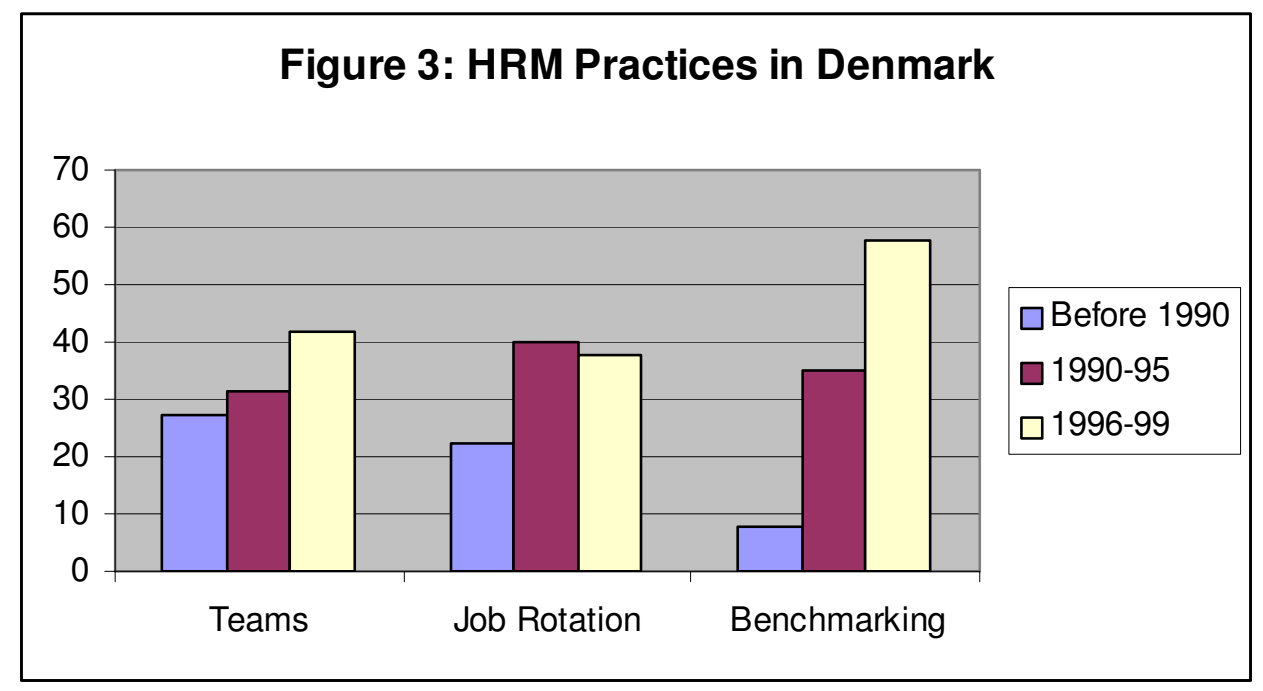

Source: Eriksson (2002) 


\section{TABLE 1}

Contributions to Growth in Labor Productivity, Using Data as of March 2002

\section{4-90}

(1)
1991-95

(2)

1996-2001

1.54

1.36

1. Growth of labor productivity ${ }^{1}$

Contributions from ${ }^{2}$

2. Capital deepening

3. Information technology capital

4. Computer hardware

5. Software

6. Communication eqúipment

7. Other capital

8. Labor quality

9. Multifactor productivity

10. Semiconductors

11. Computer hardware

12. Software

13. Communication equipment

14. Other sectors

15. Total IT contribution ${ }^{3}$
.77

.41

.23

.09

.09

.37

.22

.37

.08

.11

.04

.04

.11

.68
.52

.46

.19

.21

.05

.06

.45

.58

.13

.13

.09

.06

.17

.87
1.19

1.02

.54

.35

.13

.17

.25

.99

.42

.19

.11

.05

.23

1.79
Post-1995

change

(3) minus (2)

1 In the nonfarm business sector, measured as the average annual log difference for the years shown multiplied by 100.

2 Percentage points per year.

${ }^{3}$ Equals the sum of lines 3 and 10-13.

Note: Detail may not sum to totals because of rounding.

Source: Authors' calcuiations based on BEA and BLS data

Source: Olinor and Sichel (2003) 


\section{Table 2: Performance Effects of HRM Practices}

\begin{tabular}{|c|c|c|c|c|c|}
\hline Authors & Sample/Data & $\begin{array}{l}\text { Dependent } \\
\text { Variable }\end{array}$ & HR Measures & Results & Methods \\
\hline $\begin{array}{l}\text { Sandra E Black and } \\
\text { Lisa M Lynch - } \\
\text { What's driving the } \\
\text { new economy: the } \\
\text { benefits of } \\
\text { workplace } \\
\text { innovation (2000) }\end{array}$ & $\begin{array}{l}\text { A panel of } 766 \\
\text { establishments (drawn } \\
\text { from both manufacturing } \\
\text { and non-manufacturing } \\
\text { and with more than } 20 \\
\text { employees) was } \\
\text { constructed from the } \\
\text { EQW National Employers } \\
\text { Survey administered by } \\
\text { US Bureau of Census in } \\
1994 \text { and } 1997\end{array}$ & $\begin{array}{l}\text { Value added } \\
\text { per person }\end{array}$ & \begin{tabular}{|l|} 
Use of high \\
performance work \\
systems like re- \\
engineering, \\
benchmarking and \\
self managed teams; \\
number of managerial \\
levels; Worker \\
characteristics; \\
Technology; \\
Employee Voice and \\
Recruitment \\
strategies
\end{tabular} & $\begin{array}{l}\text { - High performance workplace } \\
\text { practices lead to higher productivity } \\
\text { and higher wages } \\
\text { There is a positive and significant } \\
\text { relationship between the use of } \\
\text { computers by non-managers, } \\
\text { undergoing re-engineering and } \\
\text { increasing employee voice and } \\
\text { productivity } \\
\text { Increasing profit sharing results in } \\
\text { lower regular pay for technical and } \\
\text { clerical/sales workers }\end{array}$ & $\begin{array}{l}\text { Regression equation for } \\
\text { the cross-sectional data } \\
\text { and for keeping the } \\
\text { establishment fixed was } \\
\text { examined the impact of } \\
\text { workplace practices and } \\
\text { worker characteristics on } \\
\text { labor productivity. The } \\
\text { standard Cobb-Douglas } \\
\text { production function is } \\
\text { augmented by allowing } \\
\text { for worker characteristics }\end{array}$ \\
\hline
\end{tabular}




\begin{tabular}{|c|c|c|c|c|c|}
\hline $\begin{array}{l}\text { Timothy F. } \\
\text { Breshnahan, Erik } \\
\text { Brynjolfsson and } \\
\text { Lorin M. Hitt - } \\
\text { Technology, } \\
\text { Organization and } \\
\text { the Demand for } \\
\text { Skilled Labor } \\
(2002)\end{array}$ & $\begin{array}{l}\text { Cross-sectional survey of } \\
\text { organizational practices } \\
\text { and labor force } \\
\text { characteristics conducted } \\
\text { during } 1995 \text { and } 1996 \\
\text { matched with panel data } \\
\text { of IT capital levels and } \\
\text { mix over } 1987-94 \text {. The } \\
\text { dataset covers } \\
\text { approximately } 400 \text { large } \\
\text { US corporations. (55 } \\
\text { percent in manufacturing, } \\
\text { mining or construction, } 45 \\
\text { percent in services) }\end{array}$ & Log output & $\begin{array}{l}\text { Team based work } \\
\text { organization; } \\
\text { individual decision } \\
\text { authority; human } \\
\text { capital levels and } \\
\text { investment; } \\
\text { composition of } \\
\text { production workers }\end{array}$ & $\begin{array}{l}\text { - The empirical evidence suggests } \\
\text { that there are three clear } \\
\text { complementarities among human } \\
\text { capital, workplace organization and } \\
\text { IT. All these play different roles in } \\
\text { the firm. } \\
\text { The falling prices of computers and } \\
\text { IT services have raised demand of } \\
\text { IT capital and led to invention of } \\
\text { new organizational forms along } \\
\text { with introduction of new products } \\
\text { and services. } \\
\text { Despite the adjustment costs and } \\
\text { rising wages of highly skilled labor, } \\
\text { firms will find the cluster of } \\
\text { complements worth adopting } \\
\text { Information technology is a source } \\
\text { of increased demand for skilled } \\
\text { labor and rising wage inequality }\end{array}$ & $\begin{array}{l}\text { Use the short and } \\
\text { intermediate run } \\
\text { production function } \\
\text { framework to explain } \\
\text { complementarities and } \\
\text { derive implications for } \\
\text { labor demand. The } \\
\text { complements that are } \\
\text { studied are: } \\
\text { cheaper, more powerful } \\
\text { IT capital; organizational } \\
\text { change and new } \\
\text { products, services or } \\
\text { quality }\end{array}$ \\
\hline $\begin{array}{l}\text { Peter Cappelli and } \\
\text { David Neumark - } \\
\text { Do high } \\
\text { performance work } \\
\text { practices improve } \\
\text { establishment level } \\
\text { outcomes (1999) }\end{array}$ & $\begin{array}{l}1997 \text { Census Bureau } \\
\text { survey of more than } \\
1,800 \text { plant and business } \\
\text { managers }\end{array}$ & $\begin{array}{l}\text { Sales per } \\
\text { worker; total } \\
\text { labor costs per } \\
\text { worker and a } \\
\text { combined } \\
\text { measure of } \\
\text { efficiency }\end{array}$ & $\begin{array}{l}\text { Use of IT, } \\
\text { benchmarking, self } \\
\text { managed teams; } \\
\text { TQM; cross-training; } \\
\text { profit sharing }\end{array}$ & $\begin{array}{l}\text { - Little consistent evidence of profit } \\
\text { sharing on productivity } \\
\text { High performance work practices } \\
\text { raise labor cost per worker } \\
\text { There are gains to workers when } \\
\text { organizations use high } \\
\text { performance work systems, but } \\
\text { there is no clear cut evidence of } \\
\text { positive impact on organizations }\end{array}$ & $\begin{array}{l}\text { Regressions model for } \\
\text { efficiency variables was } \\
\text { constructed and checked } \\
\text { effects against various } \\
\text { work practice variables }\end{array}$ \\
\hline
\end{tabular}




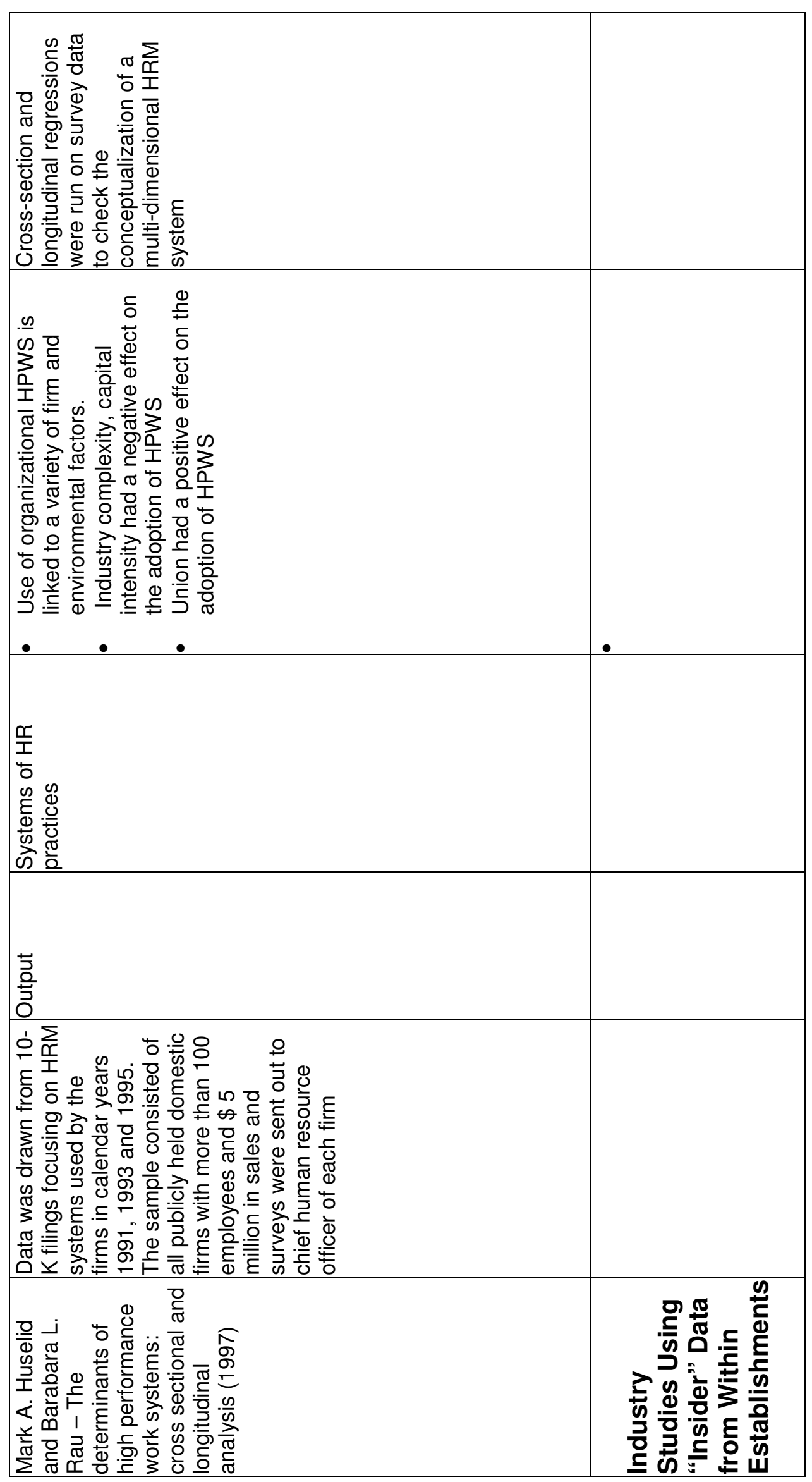




\begin{tabular}{|c|c|c|c|c|c|}
\hline $\begin{array}{l}\text { Rosemary Batt - } \\
\text { Work organization, } \\
\text { technology, and } \\
\text { performance in } \\
\text { customer service } \\
\text { and sales (1999) }\end{array}$ & $\begin{array}{l}\text { Data consisted of } \\
\text { questionnaires } \\
\text { administered to } 223 \\
\text { unionized employees in } \\
68 \text { workgroups in } \\
\text { customer service centers } \\
\text { in a large regional Bell } \\
\text { operating company }\end{array}$ & $\begin{array}{l}\text { Sales } \\
\text { productivity } \\
\text { and self } \\
\text { reported } \\
\text { quality }\end{array}$ & $\begin{array}{l}\text { Measures of human } \\
\text { resource practices } \\
\text { like skill level, } \\
\text { coaching support, } \\
\text { advancement } \\
\text { opportunities, job } \\
\text { insecurity and annual } \\
\text { earnings. Other } \\
\text { measures included } \\
\text { employment } \\
\text { relations, service } \\
\text { market location }\end{array}$ & $\begin{array}{l}\text { - Self managed team participation } \\
\text { increases sales and improved } \\
\text { perceived quality } \\
\text { - Group interaction improved the use } \\
\text { of technology presumably through } \\
\text { learning or problem solving } \\
\text { - Teams encourage individuals to } \\
\text { assume more responsibility though } \\
\text { it is not the only structure } \\
\text { - Individual discretion may lead to } \\
\text { negative impact on quality } \\
\text { Perceptions of declining job } \\
\text { security increases sales but } \\
\text { adversely impacts quality }\end{array}$ & $\begin{array}{l}\text { Data was collected from } \\
\text { observation, interviews at } \\
\text { multiple levels of the } \\
\text { organization, individual } \\
\text { surveys that were also } \\
\text { matched to performance } \\
\text { data. The model used } \\
\text { additive indices for work } \\
\text { organization and } \\
\text { multiplicative terms for } \\
\text { the work organization and } \\
\text { technological system }\end{array}$ \\
\hline \begin{tabular}{|l} 
John Paul \\
MacDuffie - Human \\
resource bundles \\
and manufacturing \\
performance: \\
organizational logic \\
and flexible \\
production systems \\
in world auto \\
industry (1995)
\end{tabular} & $\begin{array}{l}\text { International assembly } \\
\text { plant study based on } \\
1989-90 \text { survey of } 62 \\
\text { automotive assembly } \\
\text { plants }\end{array}$ & $\begin{array}{l}\text { Labor } \\
\text { productivity } \\
\text { and } \\
\text { consumer- } \\
\text { perceived } \\
\text { quality }\end{array}$ & $\begin{array}{l}\text { Total automation; } \\
\text { product design age; } \\
\text { model mix complexity } \\
\text { and parts complexity } \\
\text { Production } \\
\text { organization } \\
\text { measures like use of } \\
\text { buffers, work systems } \\
\text { and HRM policies; }\end{array}$ & $\begin{array}{l}\text { Three indices to capture systemic } \\
\text { differences in organizational logic } \\
\text { between mass production and } \\
\text { flexible production were developed } \\
\text { The assembly plants using flexible } \\
\text { production systems outperform } \\
\text { more traditional mass-production } \\
\text { systems in both quality and } \\
\text { productivity } \\
\text { There is a positive relationship } \\
\text { between innovative human } \\
\text { resource practices and economic } \\
\text { performance }\end{array}$ & $\begin{array}{l}\text { Survey data was } \\
\text { collected for the sample } \\
\text { plants and regression } \\
\text { analysis was carried. The } \\
\text { regression model was } \\
\text { based on Standard Coub- } \\
\text { Douglas production } \\
\text { function using log of } \\
\text { dependent and } \\
\text { independent variables. } \\
\text { Factor and cluster } \\
\text { analysis was also } \\
\text { performed on the data }\end{array}$ \\
\hline
\end{tabular}




\begin{tabular}{|c|c|c|c|c|c|}
\hline $\begin{array}{l}\text { John T. Dunlop and } \\
\text { David Weil - } \\
\text { Diffusion and } \\
\text { performance of } \\
\text { modular production } \\
\text { in the US apparel } \\
\text { industry (1996) }\end{array}$ & $\begin{array}{l}\text { Forty two business units } \\
\text { in men's and women's } \\
\text { garment product lines } \\
\text { collected between } 1988 \\
\text { and } 1992 \text { at the business } \\
\text { unit level }\end{array}$ & $\begin{array}{l}\text { Lead times - } \\
\text { standard and } \\
\text { shortest; and } \\
\text { operating } \\
\text { profit }\end{array}$ & $\begin{array}{l}\text { Compensation } \\
\text { practices, training } \\
\text { practices as they } \\
\text { differ from PBS and } \\
\text { modular systems }\end{array}$ & $\begin{array}{l}\text { - Slow diffusion of innovative HR } \\
\text { practices in the US apparel } \\
\text { industry due to concerns of costs } \\
\text { and labor productivity } \\
\text { Firms shipping a high percentage } \\
\text { to mass merchants and national } \\
\text { chains are more likely to adopt } \\
\text { modular systems } \\
\text { A strong relation between } \\
\text { investments in IT and adoption of } \\
\text { modular systems }\end{array}$ & $\begin{array}{l}\text { Use of Logit regression } \\
\text { models to test for the } \\
\text { determinants of modular } \\
\text { adoption }\end{array}$ \\
\hline $\begin{array}{l}\text { Maryellen R. Kelley } \\
\text { - Participative } \\
\text { bureaucracy and } \\
\text { productivity in the } \\
\text { machined products } \\
\text { sector (1996) }\end{array}$ & $\begin{array}{l}1991 \text { national telephone } \\
\text { survey of size stratified } \\
\text { random sample of } \\
\text { manufacturing } \\
\text { establishments from } 21 \\
\text { industries }\end{array}$ & \begin{tabular}{|l|} 
Total hours \\
required in the \\
machining \\
process to \\
produce one \\
item of a given \\
product type
\end{tabular} & $\begin{array}{l}\text { Work organization } \\
\text { like participative } \\
\text { bureaucracy; wage } \\
\text { and hiring policies; } \\
\text { technical education }\end{array}$ & $\begin{array}{l}\text { - Number of group based employee } \\
\text { participation mechanisms are } \\
\text { being combined in a new } \\
\text { organizational form } \\
\text { Large complex and multi-location } \\
\text { organizations rely more on formal } \\
\text { bureaucratic control } \\
\text { Group based participative } \\
\text { structures do not necessarily have } \\
\text { beneficial effects on the } \\
\text { productivity }\end{array}$ & $\begin{array}{l}\text { A regression model } \\
\text { testing the impact of } \\
\text { product quality, and } \\
\text { complexity, work } \\
\text { organization and } \\
\text { technological and } \\
\text { operational strategy is } \\
\text { used against a composite } \\
\text { measure of relative } \\
\text { efficiency }\end{array}$ \\
\hline $\begin{array}{l}\text { Eileen Appelbaum } \\
\text { and Peter Berg - } \\
\text { High Performance } \\
\text { Work Systems } \\
(1999)\end{array}$ & $\begin{array}{l}\text { Survey data for } 4000 \\
\text { employees collected } \\
\text { during } 1995-97 \text { of } 38 \\
\text { plants (14 in steel,, } 14 \text { in } \\
\text { apparel and } 10 \text { in medical } \\
\text { electronic instruments } \\
\text { and imaging) }\end{array}$ & ??? & $\begin{array}{l}\text { Horizontal } \\
\text { coordination and } \\
\text { communication; self } \\
\text { directed teams; } \\
\text { contingent pay and } \\
\text { participation }\end{array}$ & $\begin{array}{l}\text { - Competitive pressures are altering } \\
\text { the relationships among managers } \\
\text { and workers } \\
\text { Adoption of practices that engage } \\
\text { workers in decisions about } \\
\text { production and quality } \\
\text { improvements } \\
\text { - Firms are putting in place } \\
\text { contingent pay systems } \\
\text { Provide a cross-industry } \\
\text { perspective }\end{array}$ & $\begin{array}{l}\text { Survey and interviews } \\
\text { with a variety of } \\
\text { managers and union } \\
\text { officials }\end{array}$ \\
\hline
\end{tabular}


